\title{
Influence of inlet water on the biotic and abiotic variables in a fish pond
}

\author{
L. H. Sipaúba-Tavares ${ }^{*}$, P. A. Durigan ${ }^{a}$,F. A. Berchielli-Morais ${ }^{a}$ and R. N. Millan ${ }^{b}$ \\ ${ }^{a}$ Centro de Aquicultura, Universidade Estadual Paulista - UNESP, Via de Acesso Prof. Paulo D. Castellane, s/n, \\ CEP 14884-900, Jaboticabal, SP, Brazil

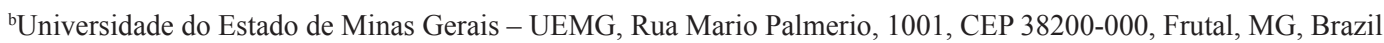 \\ *e-mail: sipauba@caunesp.unesp.br
}

Received: August 11, 2015 - Accepted: January 20, 2016 - Distributed: May 31, 2017

(With 2 figures)

\begin{abstract}
The effects of treated and untreated water inlets with macrophytes on the improvement of water quality and zooplankton community were evaluated in a fish pond with continuous water flow. Water and zooplankton samples were retrieved at four sites during nine months. There were differences $(\mathrm{p}<0.01)$ between inlet water from fish pond and inlet water from canal with macrophytes, featuring higher concentrations of nutrient load, mainly TAN and TP in the former. The inlet water from fish pond contained a higher number of abundant species (9 species), whilst the water supply from the canal with macrophytes had a greater richness (31 species) of zooplankton species. Results showed that inlet water without macrophytes directly affected the characteristics of the water column and the dominance of zooplankton species such as Thermocyclops decipiens, and greater abundance of Rotifera species. Since aquatic plants in the inlet water of fish pond analyzed showed lower allochthonous material loads from the previous fish pond, the management adopted with macrophytes may be applied to avoid eutrophication risks, common in farm ponds.
\end{abstract}

Keywords: macrophytes, zooplankton, continuous water flow, management.

\section{Influência da água de entrada sobre as variáveis bióticas e abióticas em um viveiro de piscicultura}

\begin{abstract}
Resumo
Os efeitos do abastecimento tratado e não tratado com macrófitas sobre a qualidade da água e comunidade zooplanctônica foram avaliados em um viveiro de piscicultura com fluxo contínuo de água. Houve maior concentração de fósforo total e nitrogênio amoniacal na água não tratada $(\mathrm{p}<0,01)$. Na água de entrada sem tratamento de macrófitas foi observado maior número de espécies abundantes ( 9 espécies), contudo, a entrada de água tratada com macrófitas apresentou maior riqueza de espécies ( 31 espécies) zooplanctônicas. Os resultados obtidos mostraram que a água de entrada sem macrófitas influenciou as características da coluna de água com predominância de espécies zooplanctônicas, como Thermocyclops decipiens e maior abundância de espécies de Rotifera. A água tratada com macrófita apresentou menor carga de materiais alóctones provenientes do viveiro anterior, indicando que o manejo adotado com macrófitas pode ser aplicado para evitar riscos de eutrofização, comuns em piscicultura.
\end{abstract}

Palavras-chave: macrófitas, zooplâncton, fluxo contínuo de água, manejo.

\section{Introduction}

The functioning of small water bodies, such as fish ponds, differs from lakes and reservoirs in many aspects, which include inlet water (water supply), management and spatial and vertical distribution of abiotic and biotic parameters. Intensification of freshwater aquaculture has increased pressure on water resources, and the inlet water must be sufficient to fill the pond quickly and maintain a relatively constant water level. Common water for fish ponds comprises surface run-off water, rivers, streams, springs,

wells and ground water that provide satisfactory water sources for most farm ponds (Helfrich and Pardue, 2009).

One the most important requirements for the successful development of fish ponds is an adequate inlet water where water is required to fill up fish ponds and replace water lost by evaporation and seepage (Abowei et al., 2011). Fishponds are characterized by shallowness and flow-through (southeastern Brazil). Since the water flows from one fish pond to another without any treatment, 
increase in the water nutrient load may eventually occur affecting the characteristics of the subsequent fish pond (Sipaúba-Tavares et al., 2007).

Fish ponds that receive water from the previous one may be provided with $10-15 \%$ of the average pond density of plankton community during the pond culture (Harding and Summerfelt, 1994). Boyd (2005) estimated that consumption water use in a typical trout flow-through is about $0.03 \mathrm{~m}^{3} \cdot \mathrm{kg}^{-1}$ of production or less than $0.05 \%$ of total water used. The basic aim of inlet water with continuous water flow in farm ponds is the minimization of the environmental impact by employing ecological resources as much as possible.

Macrophytes may be used to improve water quality by buffering sediments nutrients and contaminants. In fact, they absorb excessive loads of water nutrients and function as biological filters (Van der Wal et al., 2013). According to Travaini-Lima et al. (2015), macrophytes in constructed wetland system contributes towards removal of heavy metals from waste water in farm ponds of subtropical regions, mainly free floating species.

The inlet water in fish ponds is important to transport nutrients and microorganisms reflecting the conditions of the water column. The monitoring of biotic and abiotic water parameters is very important to develop and implement management strategies (Niraula, 2012). In fact, no single factor influences the success of farm ponds more than availability of an adequate supply of good water quality.

Due to insufficient knowledge on inlet water, treated or untreated with macrophytes, in farm ponds with continuous water flow, we cannot adequately predict whether this management may be a tool for the maintenance of good conditions in the inlet water through bio-filtration of organic and inorganic pollutants. Therefore, current study evaluated water inlets with and without macrophytes to assess the influence of biotic and abiotic water parameters in a fish pond.

\section{Material and Methods}

\subsection{Study area}

Current assay was carried on at farm $\left(21^{\circ} 15^{\prime} \mathrm{S} ; 48^{\circ} 17^{\prime} \mathrm{W}\right)$ featuring a fish pond measuring $8,067 \mathrm{~m}^{2}$ and $1.3 \mathrm{~m}$ deep, with a continuous water flow and water renewal (calculated from discharge volume) equivalent to $5 \%$ of total volume/day. The fish pond under analysis is the third on in a series of six similarly sized fishponds in a sequential line (Figure 1), each one, directly or indirectly, receiving water from the previous one, and from other minor earthen ponds further up the watershed. The fish pond has two water inlets. The inlet pipe (IW) at the northern end receives water from the previous large fish pond $\left(1,822 \mathrm{~m}^{2}\right)$ that contains a cage system with tilapia culture and other fish species such as Piaractus mesopotamicus (pacu), and Colossoma macropomum (tambaqui), already extant in the fish pond. Water from this large fish pond is discharged into the fish pond under analysis at a height of $1 \mathrm{~m}$ from the water surface and forms a strong water mixture (Figure 1). The other inlet water (IM) at the northeastern side opens onto a canal with macrophytes. The aquatic plants have no contact with the fish pond water due to a barrier within the inlet pipe. The canal is $10 \mathrm{~m}$ long and has a total area of $27 \mathrm{~m}^{3}$, with two macrophytes species, Althernanthera aquatica and Commelina sp. very common in the region. The water source for all fish ponds and for the pond analyzed comes from the first pond in the line (Figure 1). The water outlet lies at the southern end of the pond (Figure 1). The fish pond analyzed contains specimens of Piaractus mesopotamicus,

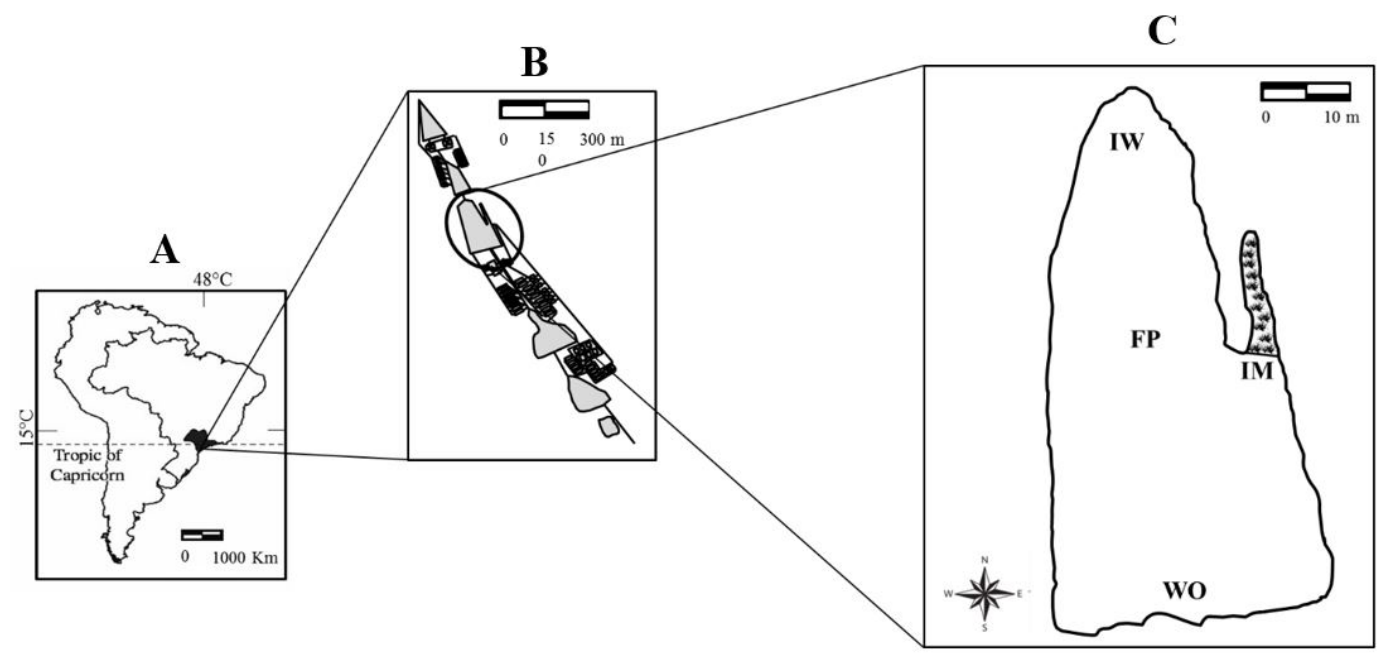

Figure 1. Cross-section of the fish pond studied, where: IM and IW = water inlets; FP = deeper water site; WO = water outlet. Inset A: shade area indicates southeastern Brazil (state of São Paulo). Inset B: farm ponds of the State University of São Paulo. Inset C: fishpond studied with sampling sites (IM, IW, FP, WO). 
Colossoma macropomum, Oreochromis niloticus, Leporinus macrocephalus, Brycon amazonicum, Cyprinus carpio, Pseudoplatystoma corruscans and Hypostomus affinis at a density of approximately $0.5 \mathrm{~kg} \cdot \mathrm{m}^{2}$. The fish are fed on a supplementary diet consisting of $3 \%$ of their weight per day.

\subsection{Environment aspects}

Water and zooplankton samples were retrieved from the surface $(0.10 \mathrm{~m})$ with a Van Dorn bottle, once a month during nine months (October 2011 to June 2012) at four sampling sites: IM = inlet water from canal with macrophytes (treated); IW = inlet pipe receiving water from the other fish ponds (untreated); $\mathrm{FP}=$ deep water site $(1.8 \mathrm{~m}) ; \mathrm{WO}=$ water outlet (Figure 1). Temperature, $\mathrm{pH}$, dissolved oxygen and conductivity were measured with a multi-probe Horiba U-10. Total phosphorus (TP), nitrite and nitrate, were quantified with a spectrophotometer, following Golterman et al. (1978), and total ammonia nitrogen (TAN) was quantified as describe by Koroleff (1976). Hardness, 5-day biochemical oxygen demand $\left(\mathrm{BOD}_{5}\right)$, total suspended solids (TSS) and total dissolved solids (TDS) were measured according to Boyd and Tucker (1992). Alkalinity was determined as describe by Mackereth et al. (1978). Water samples for microbiological analysis using the multiple-tube methods were collected in sterilized $500 \mathrm{~mL}$ flasks and taken to the laboratory in an isothermal container. The material used in the microbiological analysis (thermotolerant coliforms) was sterilized prior to use (APHA, 1995). Vertically mixed sediment samples were taken using a 4-cm-diameter PVC core up to approximately $10 \mathrm{~cm}$ deep. Sediments were air dried, gently disaggregated and dried in a convection oven at $70{ }^{\circ} \mathrm{C}$ until completely dry. Organic matter $\left(\mathrm{OM}_{\text {sed }}\right)$ and total phosphorus $\left(\mathrm{TP}_{\text {sed }}\right)$ were calculated following methods described by Andersen (1976). Analyses were performed immediately after sampling or samples were duly stored under refrigeration. Meteorological conditions during the sampling period with regard to daily average air temperature and rainfall were $25.9^{\circ} \mathrm{C}$ and $53.6 \mathrm{~mm}$ between October and March, and $19.5^{\circ} \mathrm{C}$ and $3.3 \mathrm{~mm}$ between April and June, respectively.

In case of zooplankton, $10 \mathrm{~L}$ of water were filtered by $58 \mu \mathrm{m}$ pore net, concentrated to $50 \mathrm{~mL}$, whilst formaldehyde was added to reach $4 \%$ of final concentration. The net samples were observed under an optical microscope for preliminary taxonomical identifications. Cladocera and Copepoda species were counted in a reticulated acrylic chamber under a stereoscopic microscope (40 x) and Rotifera were analyzed by Sedgewick-Rafter counting cell and examined under a Leitz microscope (100 x). Taxonomic identification followed specialized literature (Koste, 1978; Reid, 1985; Elmoor-Loureiro, 1997; Silva and Matsumura-Tundisi, 2005).

\subsection{Statistical analysis}

Statistical analyses were carried out with Statistica 8.0. A one-way analysis of variance (ANOVA), and post-hoc Tukey's HSD multiple comparison test were conducted for physical and chemical parameters to compare water inlets (IM and IW), FP and WO sites, at $\mathrm{p}<0.01$ significance level (Fowler et al., 1998). In all cases, ANOVA test was preceded by a test of variance homogeneity (Levene's test) and the analysis of dominance and abundance of species conducted for zooplankton. Species were dominant when density was higher than $50 \%$ of the total number of specimens present; they were abundant when the number of specimens was higher than the mean density of all occurring species (Lobo and Leighton, 1986). The Shannon-Wiener (H') and richness (total number of species) were used to analyse the diversity of zooplankton at the study sites during the experiment (Odum and Barrett, 2005).

\section{Results}

No significant difference $(\mathrm{p}>0.05)$ was reported between sites with regarded to alkalinity, hardness, temperature, conductivity, TDS and TSS. Contrasting, TAN, BOD, nitrate, dissolved oxygen, total phosphorus, nitrite and $\mathrm{pH}$ were significantly different $(\mathrm{p}<0.05)$ among sampled sites (Table 1). Total ammonia nitrogen concentrations were higher in IW $(p<0.01)$ than in IM site, which was more associated with fish feeding management (addition of food). Concentrations of TAN in the inlet water from the canal with macrophytes (IM) were lower $(p<0.01)$ than those at IW and WO. Total ammonia nitrogen and dissolved oxygen were respectively about $53 \%$ and $40 \%$ higher at IW than at IM. Nitrate concentrations were different $(\mathrm{p}<0.01)$ at IM and ranged, between $12 \mu \mathrm{g}$. $\mathrm{L}^{-1}$ and $932 \mu \mathrm{g} . \mathrm{L}^{-1}$ (Table 1). Water inlets IM and IW had lower $(\mathrm{p}<0.01)$ of $\mathrm{BOD}_{5}$ and nitrite concentrations than FP and WO. Phosphorus concentrations were lower in water inlets than at the other sites through the analyzed period (Table 1).

The $\mathrm{pH}$ was acid during the research period. At IW and WO sites the $\mathrm{pH}$ values were similar but at IM site was more acid water. Low alkalinity concentrations were observed in all sample sites $(\mathrm{p}>0.05)$. The sediment presented high organic matter (above 4\%), and the highest concentrations were reported at WO, with $17 \%$ during the sampling period. Phosphorus concentrations in the sediment were low and similar at all sites (Table 1). The highest number of thermotolerant coliforms (1,600 MPN.100 mL $\left.\mathrm{mL}^{-1}\right)$ was reported during the fish growth period and rainy conditions, between November and January but below 220 MPN.100 $\mathrm{mL}^{-1}$ during the other months (Figure 2).

Nutrients concentrations seemed to affect Rotifera density. The species, Asplanchna sp., Brachionus caudatus, Keratella cochlearis, Lecane bula, Proales doliaris, Trichocerca cavia and T. longiseta were present during the sampling period. Ascomorpha ecaudis, Asplanchna sp., Brachionus calyciflorus, Kellicottia longispina and Polyarthra dolichoptera were abundant at FP (67\%) and WO (70\%). Only P. doliaris was abundant at IM, Brachionus caudatus, Pompholyx triloba, P. doliaris and T. cavia were abundant at IW (Table 2). Rotifera showed 
Table 1. Physical and chemical variables of water samples, total phosphorus $\left(\mathrm{TP}_{\text {sed }}\right)$ and organic matter $\left(\mathrm{OM}_{\text {sed }}\right)$ in the sediment of the fish pond at different sites (IM, IW, FP, WO) during the sampling period. (Mean \pm standard deviation).

\begin{tabular}{|c|c|c|c|c|}
\hline \multirow{2}{*}{ PARAMETERS } & \multicolumn{4}{|c|}{ SITES } \\
\hline & IM & IW & FP & WO \\
\hline Nitrate $\left(\mu \mathrm{g} . \mathrm{L}^{-1}\right)$ & $639 \pm 362^{\mathrm{a}}$ & $307 \pm 164^{b}$ & $427 \pm 174^{\mathrm{ab}}$ & $458 \pm 188^{\mathrm{ab}}$ \\
\hline Nitrite $\left(\mu \mathrm{g} . \mathrm{L}^{-1}\right)$ & $9.8 \pm 4.7^{\mathrm{ab}}$ & $9.7 \pm 2.9^{b}$ & $13.2 \pm 1.7^{\mathrm{ab}}$ & $13.4 \pm 1.6^{\mathrm{a}}$ \\
\hline $\operatorname{TAN}\left(\mu \mathrm{g} \cdot \mathrm{L}^{-1}\right)$ & $48 \pm 36^{\mathrm{b}}$ & $91 \pm 28^{\mathrm{a}}$ & $70 \pm 16^{\mathrm{ab}}$ & $84 \pm 16^{\mathrm{a}}$ \\
\hline $\mathrm{TP}\left(\mu \mathrm{g} \cdot \mathrm{L}^{-1}\right)$ & $20 \pm 19^{c}$ & $32 \pm 18^{\mathrm{bc}}$ & $56 \pm 19^{\mathrm{ab}}$ & $62 \pm 30^{\mathrm{a}}$ \\
\hline $\mathrm{DO}\left(\mathrm{mg} \cdot \mathrm{L}^{-1}\right)$ & $3.3 \pm 1.1^{\mathrm{c}}$ & $5.5 \pm 0.4^{\mathrm{b}}$ & $7.8 \pm 1.7^{\mathrm{a}}$ & $7.2 \pm 1.5^{\mathrm{a}}$ \\
\hline Conductivity $\left(\mu \mathrm{S} . \mathrm{cm}^{-1}\right)$ & $59 \pm 7.5^{\mathrm{a}}$ & $53 \pm 6.1^{\mathrm{a}}$ & $55 \pm 3.5^{\mathrm{a}}$ & $55 \pm 3.5^{\mathrm{a}}$ \\
\hline TSS $\left(m g . L^{-1}\right)$ & $8.7 \pm 6.2^{\mathrm{a}}$ & $6.6 \pm 5.9^{\mathrm{a}}$ & $11 \pm 5.3^{\mathrm{a}}$ & $9.8 \pm 9.4^{\mathrm{a}}$ \\
\hline TDS (mg. $\left.\mathrm{L}^{-1}\right)$ & $156 \pm 70^{\mathrm{a}}$ & $97 \pm 108^{\mathrm{a}}$ & $101 \pm 106^{\mathrm{a}}$ & $135 \pm 82^{\mathrm{a}}$ \\
\hline $\mathrm{pH}$ & $5.2 \pm 0.4^{b}$ & $5.5 \pm 0.3^{\mathrm{ab}}$ & $6.5 \pm 1^{\mathrm{a}}$ & $5.9 \pm 0.6^{\mathrm{ab}}$ \\
\hline Temperature $\left({ }^{\circ} \mathrm{C}\right)$ & $22.6 \pm 4.0^{\mathrm{a}}$ & $24 \pm 3.2^{\mathrm{a}}$ & $25 \pm 3.7^{\mathrm{a}}$ & $24.9 \pm 3.7^{\mathrm{a}}$ \\
\hline Alkalinity $\left(\mathrm{mg} \cdot \mathrm{L}^{-1}\right)$ & $25 \pm 4.3^{\mathrm{a}}$ & $24 \pm 2.8^{\mathrm{a}}$ & $27 \pm 2.6^{\mathrm{a}}$ & $26 \pm 2^{\mathrm{a}}$ \\
\hline $\mathrm{BOD}_{5}\left(\mathrm{mg} \cdot \mathrm{L}^{-1}\right)$ & $3.3 \pm 1.6^{\mathrm{b}}$ & $2.8 \pm 1.1^{\mathrm{b}}$ & $6.9 \pm 3.8^{\mathrm{a}}$ & $7 \pm 2.7^{\mathrm{a}}$ \\
\hline Hardness (mg. $\left.L^{-1}\right)$ & $19 \pm 2.3^{\mathrm{a}}$ & $19 \pm 2.1^{\mathrm{a}}$ & $20 \pm 1.8^{\mathrm{a}}$ & $20 \pm 1.9^{\mathrm{a}}$ \\
\hline $\mathrm{TP}_{\text {sed }}\left(\mu \mathrm{gP} \cdot \mathrm{g}^{-1}\right)$ & $0.4 \pm 0.2^{\mathrm{a}}$ & $0.5 \pm 0.3^{\mathrm{a}}$ & $0.5 \pm 0.1^{\mathrm{a}}$ & $0.4 \pm 0.2^{\mathrm{a}}$ \\
\hline $\mathrm{OM}_{\text {sed }}(\%)$ & $9.6 \pm 2.6^{\mathrm{b}}$ & $7 \pm 3.4^{\mathrm{bc}}$ & $9 \pm 2.6^{b}$ & $10 \pm 3.2^{\mathrm{ab}}$ \\
\hline
\end{tabular}

Same letter in the superscript means no differences between sites after ANOVA test $(\mathrm{p}<0.05)$.

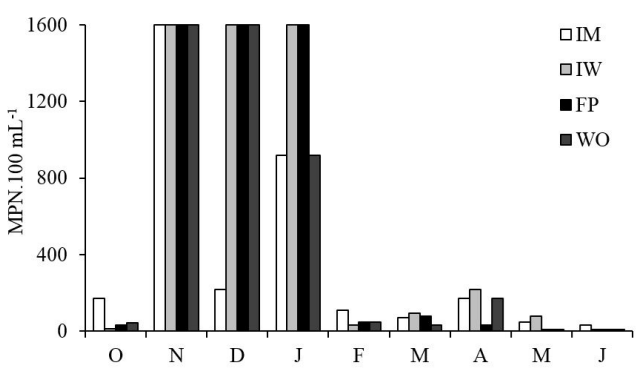

Figure 2. Monthly variation (MNP.100 $\left.\mathrm{mL}^{-1}\right)$ of thermotolerant coliforms in the water samples of the fish pond (IM, IW, FP, WO) during the sampling period.

the highest number of taxa (36) but low density when compared with the Copepoda species dominant in the water outlet (WO), represented by two species, Argyrodiaptomus furcatus and Thermocyclops decipiens. Copepoda species were abundant and dominant and/or present throughout the sampling period, except $T$. decipiens nauplii, which was absent only at IW (Table 2). Copepoda species were the most representative in the fish pond under analysis. Cladocera species consisted of five taxa, Alona monacantha, Bosmina freyi, Diaphanosoma birgei and Moina micrura were abundant in the water inlets, and $D$. birgei was also abundant at FP and WO; and Bosmina hagmanni absent at WO (Table 2). Species richness and diversity (H') were highest at FP and contributed with a higher number of zooplankton species (Table 2).

\section{Discussion}

In the farm ponds under analysis, the water (with organic and inorganic material load) passes from one fish pond to the next without treatment. Management in fish feed (daily addition of food) may further enhance the risk of deterioration of the water column with species and unfavorable physical-chemical conditions to farm ponds. Particularly in semi-intensive aquaculture systems, artificial food may be provided directly to fish or nutrients may be supplied to the environment, which in turn increases the plankton community or causes eutrophication in the water column. The above may explain the high TP and TAN at IW, FP and WO when compared to IM. Farm pond enriches the water column with dissolved organic and inorganic nutrients and affects the dissolved oxygen. Low dissolved oxygen levels at IM may be associated with aquatic plants. However, dissolved oxygen was higher at IW due to the water supply in the fish pond which was introduced at a height with strong water mixing and oxygenation of site.

Human activities in the fish pond introduce allochthonous materials that influence physical and chemical parameters from one season to another (Davies et al., 2009). Management or rather, the daily introduction of fish feed plus heavy rain that occurs during the period (runoff allochthonous material), enhanced the number of thermotolerant coliforms betwenn November to January (rainfall above $60 \mathrm{~mm}$ ). High concentrations of $\mathrm{DBO}_{5}$ at $\mathrm{FP}$ and $\mathrm{WO}$ (rainy period) were due to high levels of allochthonous material in the fish pond which influenced acid $\mathrm{pH}$ caused by the decomposition of organic matter. However, low alkalinity $\left(<30 \mathrm{mg} \cdot \mathrm{L}^{-1}\right)$ at the analyzed sites in the fish pond has been associated with $\mathrm{pH}$, mainly below 6.0 . 
Table 2. Specific composition $(+,-)$, abundance $(\mathrm{a}, \mathrm{d})$ and ecological indices (diversity and species richness) of zooplankton taxa in the fish pond at sites (IM, IW, FP, WO) during the sampling period, where: $+=$ presence; - = absence, $a=$ abundant; $\mathrm{d}=$ dominant.

\begin{tabular}{|c|c|c|c|c|c|}
\hline \multirow{3}{*}{ TAXA } & & IM & IW & FP & WO \\
\hline & diversity (H') & 1.491 & 1.398 & 1.518 & 1.462 \\
\hline & species richness & 31 & 26 & 33 & 29 \\
\hline \multicolumn{6}{|l|}{ Cladocera } \\
\hline Alona monacantha Sars, 1901 & & a & + & + & + \\
\hline Bosmina hagmanni Stingelin, 1904 & & + & + & + & - \\
\hline Bosmina freyi DeMelo \& Hebert, 1994 & & a & a & + & + \\
\hline Diaphanosoma birgei Korinek, 1981 & & + & a & a & $\mathrm{a}$ \\
\hline Moina micrura Kurz, 1874 & & a & $\mathrm{a}$ & + & + \\
\hline
\end{tabular}

\section{Copepoda}

Argyrodiaptomus furcatus Sars, 1901

nauplii

Thermocyclops decipiens Lowndes, 1934

nauplii

$\begin{array}{llll}a & a & a & d \\ a & a & a & a \\ a & a & a & d \\ a & - & + & +\end{array}$

\section{Rotifera}

Anuraeopsis navicula Rousselet, 1910

Ascomorpha ecaudis Perty, 1850

Asplanchna sp

Brachionus calyciflorus Pallas, 1766

Brachionus caudatus Barrois \& Daday, 1894

Brachionus falcatus Zacharias, 1898

Brachionus patulus Pallas, 1766

Brachionus quadridentatus Hermann, 1783

Colurella dicentra Hauer, 1924

Filinia longiseta Ehrenberg, 1834

Hexarthra intermedia Wiszniewski, 1929

Kellicottia longispina Kellicott, 1879

Keratella americana Carlin, 1943

Keratella cochlearis Gosse, 1851

Lecane bula Gosse, 1886

Lecane elsa Hauer, 1931

Lecane leontina Turner, 1892

Lecane luna Muller, 1776

Lecane lunaris Ehrenberg, 1832

Lecane monostyla Daday, 1897

Lecane quadridentata Ehrenberg, 1832

Lepadella ovalis Muller, 1786

Lepadella patella Muller, 1786

Macrochaetus subquadratus Perty, 1850

Monommata arndti Remane, 1933

Polyarthra dolichoptera Idelson, 1925

Pompholyx triloba Pejler, 1957

Proales decipiens Ehrenberg, 1832

Proales doliaris Rousselet, 1895

Proales globulifera Hauer, 1921

Proalinopsis caudatus Collins, 1872

Trichocerca elongata Gosse, 1886

Trichocerca cavia Gosse, 1886

Trichocerca longiseta Schrank, 1802

Trichocerca similis Wierzejski, 1893

Trichocerca gracilis Tessin, 1890

\begin{tabular}{|c|c|c|}
\hline+ & - & + \\
\hline- & - & + \\
\hline+ & + & $\mathrm{a}$ \\
\hline+ & - & $\mathrm{a}$ \\
\hline+ & $\mathrm{a}$ & + \\
\hline- & + & + \\
\hline+ & + & - \\
\hline- & + & + \\
\hline+ & - & - \\
\hline- & - & - \\
\hline- & - & + \\
\hline- & - & + \\
\hline- & + & + \\
\hline+ & + & + \\
\hline+ & + & + \\
\hline- & + & + \\
\hline+ & - & + \\
\hline+ & - & - \\
\hline+ & + & + \\
\hline+ & + & - \\
\hline+ & - & - \\
\hline+ & - & + \\
\hline+ & - & + \\
\hline- & - & + \\
\hline+ & - & - \\
\hline+ & - & $\mathrm{a}$ \\
\hline- & $\mathrm{a}$ & - \\
\hline- & + & - \\
\hline $\mathrm{a}$ & $\mathrm{a}$ & + \\
\hline+ & + & + \\
\hline+ & - & + \\
\hline+ & - & + \\
\hline+ & $\mathrm{a}$ & + \\
\hline+ & + & + \\
\hline+ & + & - \\
\hline- & - & + \\
\hline
\end{tabular}


Fish pond with continuous water flow, such as under analyzis, receive large amount of allochthonous materials (uneaten food, faeces, soluble waste and manure) that may have caused the high concentration of conductivity $\left(>48 \mu \mathrm{Scm}^{-1}\right)$ in the water and organic matter $(>7 \%)$ in the sediment. Boyd et al. (2002) recommended that organic matter concentration in fish pond sediment should vary between $1 \%$ and $3 \%$. Total phosphorus concentrations in the sediment were low $\left(<0.8 \mu \mathrm{gP}^{-g^{-1}}\right)$. Organic matter in submerged soils may restrict fixation of added phosphorus into iron and aluminium phosphate owing to the reduction of reactions and even chelating effects which inhibit phosphorus transformation into soluble forms (Chattopadhyay et al., 2003).

Nutrients were also affected by fishpond management (anthropic activities) and water flow. Low ammonia concentrations during the study period may have reflected with high concentrations of nitrate $\left(>150 \mu \mathrm{g} . \mathrm{L}^{-1}\right)$. In fact, nitrate is the most stable form of dissolved inorganic nitrogen for the building of nitrogen at high biomass (Sumagaysay-Chavoso and Diego-McGlone, 2003). Average water temperature in the fish pond under analysis ranged between 22.6 and $25^{\circ} \mathrm{C}$, with a good potential for fish production and growth and food conversion, better than at low temperatures (Osman et al., 2010).

The remaining nitrogen and phosphorus mainly stimulate bacteria, fungi and protozoa production which, in turn, may be consumed by zooplankton (Ferdous and Muktadir, 2009). Rotifera species in the fish pond under analysis revealed a great number of species. High abundance of several Rotifera species emphasized the effect of the management in the fish pond, contributing to a favorable environment for r-strategist organisms. Souza et al. (2008) reported that higher densities of Brachionus calyciflorus occurred owing to its great tolerance to extremely eutrophic environments. Pond depth and water flow had a positive effect on the diversity of aquatic organisms, with a high number of zooplankton species, particularly Rotifera (Sipaúba-Tavares et al., 2011).

Dominance of $T$. decipiens and $A$. furcatus adults at WO and their abundance at all sites were due to high concentration of nutrients mainly in water outlet (WO). The water flow brings allochthonuous material (anthropic activities) resulting in an eutrophication process. According Tibúrcio et al. (2015) abundance of the community of Copepoda increases due to alterations in environmental variables caused by the increase in the practice of fish farming. Themocyclops decipiens and A. furcatus adults were frequently abundant and shared habits in oligo-mesotrophic environments (Sipaúba-Tavares et al., 2011; Tibúrcio et al., 2015).

Reduction of waste food and organic matter, refinement of water inlet and decrease in nutrients, such as nitrogen and phosphorus, have been reported in the inlet water with macrophytes. Further, this kind of ecological management may optimize risk avoidance associated with eutrophication and impairment of farm pond. Current study revealed the importance of in-depth understanding of water inlets in fish ponds with continuous water flow with regard to the use of ecological resources such as macrophytes in shallow canal with high residence time. The above results in the removal of sediment that may produce unfavorable conditions in the water column, and appropriated inlet water with inclination and/or a height of $1 \mathrm{~m}$ from the water surface forming a strong water mixture that reduces levels of total phosphorus and total ammonia nitrogen and improvement of water oxygenation. However, since the fish pond has a continuous water flow and receives water from another fish pond, affecting biotic and abiotic variables, frequent monitoring at water inlet should be undertaken.

\section{Acknowledgements}

The authors would like to thank the Brazilian Council for Scientific and Technological Development (CNPq) for financial support. The authors would also like to thank the working group of the Limnology and Plankton Production Laboratory of CAUNESP.

\section{References}

ABOWEI, J.F.N., AKANKALI, J.A. and ELI, A., 2011. Pond fish culture facilities in Nigeria. International Journal of Animal and Veterinary Advances, vol. 3, no. 3, pp. 212-228.

AMERICAN PUBLIC HEALTH ASSOCIATION - APHA, 1995. Standard methods for the examination of water and wastewater. 19th ed. Washington: APHA. $1100 \mathrm{p}$.

ANDERSEN, J.M., 1976. An ignition method for determination of total phosphorus in lake sediments. Water Research, vol. 10, no. 4, pp. 329-331. http://dx.doi.org/10.1016/0043-1354(76)90175-5.

BOYD, C.E., 2005. Water use in aquaculture. World Aquaculture, vol. 36 , no. 3, pp. 12-13.

BOYD, C.E. and TUCKER, C.S., 1992. Water quality and pond soil analyses for aquaculture. Alabama: Agricultural Experiment Station. 183 p.

BOYD, C.E., WOOD, C.W. and THUNJAI, T., 2002. Aquaculture pond bottom soil quality management. Cowallis: Oregon State University.

CHATTOPADHYAY, G.N., MUKHERJEE, R. and BANERJEE, A., 2003. Phosphorus management for fish ponds located in red and lateritic soil zones. Better Crops International, vol. 17, no. 2, pp. 18-21.

DAVIES, O.A., ABOWEI, J.F.N. and OTENE, B.B., 2009. Seasonal abundance and distribution of plankton of Minichinda stream, Niger Delta, Nigeria. America of Journal Science Research, vol. 2, no. 2 , pp. 20-30.

ELMOOR-LOUREIRO, L.M.A., 1997. Manual de identificação de cladóceros límnicos do Brazil. Taguatinga: Editora UniversaUCB. 156 p.

FERDOUS, Z. and MUKTADIR, A.K.M., 2009. A review: potentially of zooplankton as bio-indicator. American Journal of Applied Sciences, vol. 6, no. 10, pp. 1815-1819. http://dx.doi. org/10.3844/ajassp.2009.1815.1819.

FOWLER, J., COHEN, L. and JARVIS, P., 1998. Practical statistics for field biology. 2nd ed. New York: John Wiley and Sons. 259 p. 
GOLTERMAN, H.L., CLYMO, R.S. and OHNSTAD, M.A.M., 1978. Methods for physical and chemical analysis of fresh water. 2nd ed. Oxford: Blackwell Scientific Publication. 213 p. IBP Handbook, no. 8.

HARDING, L.M. and SUMMERFELT, R.C., 1994. Effects of fertilization and fry stocking density on pond production of fingerling walleye, Stizostedion vitreum. Journal of Applied Aquaculture, vol. 2, no. 3-4, pp. 59-79. http://dx.doi.org/10.1300/ J028v02n03_04.

HELFRICH, L.A. and PARDUE, G.B., 2009. Pond construction: some practical considerations. Virginia: Virginia State University. 4 p.

KOROLEFF, F., 1976. Determination of ammonia. In: E. GRASHOF and E. KREMLING, eds. Methods of seawater analysis. German: Verlag Chemie Weinhein, pp. 126-133.

KOSTE, W., 1978. Rotatoria. Berlin: Borntraeger. vol. 2, 673 p.

LOBO, E. and LEIGHTON, G., 1986. Estruturas comunitarias de las fitocenozes plakctonicas de los sistemas de desembocaduras y esteros de rios de la zona central de Chile. Revista de Biologia Marina, vol. 22, pp. 1-29.

MACKERETH, F.J., HERON, H.J. and TALLING, F.J., 1978. Water analyses: some revised methods for limnologists. Freshwater Publication Association Scientific Publication, vol. 35, pp. 22-117.

NIRAULA, R., 2012. Evaluation of the limnoloical status of Beehazar lake, a ramasar site in central Nepal. Journal of Water Resource and Protection, vol. 4, no. 5, pp. 256-263. http://dx.doi. org/10.4236/jwarp.2012.45028.

ODUM, E.P. and BARRETT, G.W., 2005. Fundamentals of ecology. Belmont: Thomson Brooks/Cole. 598 p.

OSMAN, M.A., MOHAMED, M.H.H. and AL-AFITY, A.D.G., 2010. Assessment of agriculture drainage water quality to be used for fish farm irrigation. Nature and Science, vol. 8, no. 8, pp. 60-74.

REID, J.W., 1985. Calanoid copepods (Diaptomidae) from coastal lakes. State of Rio de Janeiro. Brazil. Proceedings of the Biological Society of Washington, vol. 98, no. 1, pp. 574-590.

SILVA, W.M. and MATSUMURA-TUNDISI, T., 2005. Taxonomy, ecology, and geographical distribution of the species of the genus Thermocyclops kiefer, 1927 (Copepoda, Cyclopoida) in São Paulo
State, Brazil, with description of a new species. Brazilian Journal of Biology = Revista Brasileira de Biologia, vol. 65, no. 3, pp. 521-531. http://dx.doi.org/10.1590/S1519-69842005000300018. PMid:16341431.

SIPAÚBA-TAVARES, L.H., DONADON, A.R.V. and MILLAN, R.N., 2011. Water quality and plankton populations in an earthen polyculture pond. Brazilian Journal of Biology $=$ Revista Brasileira de Biologia, vol. 71, no. 4, pp. 1-11. http://dx.doi.org/10.1590/ S1519-69842011000500005.

SIPAÚBA-TAVARES, L.H., GUARIGLIA, C.S.T. and BRAGA, F.M.S., 2007. Effects of rainfall on water quality in six sequentially disposed fishponds with continuous water flow. Brazilian Journal of Biology = Revista Brasileira de Biologia, vol. 67, no. 4, pp. 643-649. http://dx.doi.org/10.1590/S1519-69842007000400008. PMid:18278315.

SOUZA, W., ATTAYDE, J.L., ROCHA, E.S. and ESKINAZISANT'ANNA, E.M., 2008. The response of zooplankton to variations in the water quality of four man-made lakes in semiarid northeastern Brazil. Journal of Plankton Research, vol. 30, no. 6 , pp. $699-708$

SUMAGAYSAY-CHAVOSO, N.S. and DIEGO-MCGLONE, M.L.S., 2003. Water quality and holding capacity of intensive and semi-intensive milkfish (Chanos chanos) ponds. Aquaculture, vol. 219, no. 1, pp. 413-429. http://dx.doi.org/10.1016/S00448486(02)00576-8.

TIBÚRCIO, V.G., ARRIEIRA, R.L., SCHWIND, L.T.F., BONECKER, C.D.C. and LANSAC-TÔHA, F.A., 2015. Effects of nutrients increase on the copepod community of a reservoir using cage. Acta Limnologica Brasiliensia, vol. 27, no. 3, pp. 265-274. http://dx.doi.org/10.1590/S2179-975X0315.

TRAVAINI-LIMA, F., VEIGA, M.A.M.S. and SIPAÚBATAVARES, L.H., 2015. Constructed wetland for treating effluent from subtropical aquaculture farm. Water, Air, and Soil Pollution, vol. 226 , no. 42 , pp. 2-10.

VAN DER WAL, J.E., DORENBOSCH, M., IMMERS, A.K., VIDAL FORTEZA, C., GEURTS, J.J., PEETERS, E.T., KOESE, B. and BAKKER, E.S., 2013. Invasive crayfish threaten the development of submerged macrophytes in lake restoration. PLoS One, vol. 8, no. 10, pp. 1-11. PMid:24205271. 